\title{
Dynamics of Canadian Trade Pattern: A Time-Series Analysis
}

\author{
Hussein Al-Zyoud ${ }^{1} \&$ Fathi Elloumi $^{1}$ \\ ${ }^{1}$ Faculty of Business, Athabasca University, Alberta, Canada \\ Correspondence: Hussein Al-Zyoud, Faculty of Business, Athabasca University, Edmonton, AB, T5L 4W1, \\ Canada. Tel: 1-780-457-7534. E-mail: husseina@ athabascau.ca
}

Received: December 22, 2016

Accepted: January 24, $2017 \quad$ Online Published: February 15, 2017

doi:10.5539/ijef.v9n3p115

URL: http://dx.doi.org/10.5539/ijef.v9n3p115

\begin{abstract}
This paper analyses the trends and directions of exports and imports of Canada using the time series data for the period 1981 to 2014. Instantaneous and compound growth rates are calculated by using the log-linear regression model in conjunction with an autoregressive integrated moving average (ARIMA) model for forecasting future exports and imports. The results of this study show that there is an increasing trend for both exports and imports. As far as the growth rates are concerned, the two estimated log-linear models depict a comprehensive annual picture of Canadian merchandise trade. The exports grow at an instantaneous rate of $4.46 \%$ and at a slightly higher than compound annual growth rate of $4.6 \%$. The overall growth rate of imports is $5.41 \%$ and compound annual growth rate is $5.27 \%$. The compound growth rate is marginally higher than the instantaneous growth rate.

The results of the Johansen test for analyzing the long-run relationship between export, import and GDP have further demonstrated that the variables are co-integrated, and have established a long-run association among them.
\end{abstract}

Keywords: trends, growth, instantaneous, exports, imports, ARIMA

\section{Introduction}

Canada is among the top producers and suppliers of many commodities, such as crude oil, cars, chemical fertilizers, lumber, seafood, etc. The country is an important economic player in the world economy, and its economic importance is expected to increase in the future given the continuous increase in demand for durables and non-durables goods. The economic literature emphasizes the interdependence of exports and imports on national economies and explains how national economies are linked to each other. In today's globalized trade, a finished product of one industry becomes an input for another industry. This interdependence among the countries also points out that considering both the home country environment as well as that prevailing in the international boundaries, is vital for determining the countries trade patterns and its related dynamics.

Since the earliest beginnings, Canada has relied upon international exports as an important source of national income. Canada's economy is highly integrated with the U.S. economy, and Canada shares the world's largest trading relationship with the United States. During the early nineties international trade agreements have changed the 'playing field' for production and trade openness. Most notably for Canada and the U.S. are the North American Free Trade Agreement (NAFTA, 1994) and the Agreement of Internal Trade (AIT, 1995). U.S. and Mexico emerged as the latest market entrants after manufacturers faced stiffer competition at home; the total merchandise trade has more than doubled since. Fueled by a low dollar and strong foreign demand total exports in Canada increased by more than $11 \%$ per annum on average, between 1990 and 1996. (Statistics Canada, 1999b).

Crude oil occupies the most dominant position in Canada's export category. According to the U.S. energy information administration, Canada is the world's sixth largest oil producer with an estimated 3.6 million barrels produced per day. It is also the eleventh largest car manufacturer in the world. In 1990, it is estimated that three-quarters of Canadian merchandise exports were heading for the U.S. By 1996, this proportion had increased to $82 \%$ (Statistics Canada, 1999a). The merchandise imports from the U.S., on the other hand, rose from 66\% in 1990 to 69\% in 1996 (Statistics Canada, 1999b). In 2012, U.S./Canada merchandise trade consisted of U.S. $\$ 324.2$ billion in imports and U.S. \$292.4 billion in exports.

The third largest export from Canada is currently gold; the primary Canadian export of natural gas has moved Canada to the world's third largest producer of gas behind Russia and the United States. 
Table 1. Significant merchandise exports from Canada during 2015

\begin{tabular}{cccccccc}
\hline Energy & $\begin{array}{c}\text { Motor } \\
\text { Vehicles }\end{array}$ & $\begin{array}{c}\text { Mechanical Machinery } \\
\text { \& Equipment }\end{array}$ & $\begin{array}{c}\text { Precious Stones \& } \\
\text { Metals }\end{array}$ & $\begin{array}{c}\text { Electrical Machinery } \\
\text { \& Equipment }\end{array}$ & $\begin{array}{c}\text { Plastics } \\
\text { A }\end{array}$ & $\begin{array}{c}\text { Aircraft, } \\
\text { Spacecraft \& parts }\end{array}$ & $\begin{array}{c}\text { Wood \& } \\
\text { Articles }\end{array}$ \\
\hline \$99.1billion & $\$ 76.8$ billion & $\$ 39.7$ billion & \$24.5 billion & 16.9 billion & 15.9 Billion & 15.8 billion & 15 billion \\
\hline Source; Stat Canada. & & & & & &
\end{tabular}

The main trade partners of Canada are US, China, United Kingdom, Japan, Mexico, India, South Korea, Germany, France, Italy, Russia, Spain, Brazil, Australia, Netherland, Turkey, Poland Indonesia, Belgium, Saudi Arabia, Norway, Thailand and Singapore.

The present study aims at analyzing the growth patterns or trends in Canadian exports and imports. A detailed focus has been placed on the share of exports and imports in terms of the national economy's GDP during the study period. Another dimension of this study is to forecast Canadian Merchandise export and import. Such an analysis of the entire situation of exports, imports, and GDP of an economy plays a crucial role in determining future policies pertaining to international trade, as well as achieving targeted growth rates. An assessment of the effects of the recent energy crisis on the concerned economic variables would also help the decision makers, and the concerned authorities, in efficiently planning their budgets, yearly plans, and foreign trade policies so as to avoid any negative situation in the future.

The remainder of this paper is structured as follows: a review of literature is discussed in Section 2; methodology and data sources are discussed in Section 3; Section 4 explains some background data regarding the pattern of Canadian international trade, and section 5 discusses empirical results. Conclusions are given in the final section.

\section{Review of Relevant Literature}

For many decades the world economy has grown and shifted with the increase of tradable goods and production components. National policies which have focused on the reduction of international trade barriers have been suggested as the major contributing factor (Dion, 2000). The resulting decrease in prices of goods has also been contributed to by technological progress which has made transportation, communication, and development of tradable goods less expensive (Dion, 2000). The Canadian percentage of this expanding global trade movement, as with other developing and developed nations, has grown faster than national economic figures such as GDP or gross output of goods.

The relationship between GDP and Gross Output of Goods is important to understanding the true effect of exports-imports on the national economy. Particularly since GDP is often discussed in relationship to economy-wide incomes and used by governments and businesses to support policy initiatives (seen in Bloski, Clarke, \& Gellatly, 2015). A. Abdulai and P. Jaquet (2012) found in their study support for the export-driven GDP growth hypothesis of Cote d' Ivoire. The effects of international exports and imports have come to play an important role in a countries economic situation (Hruzova, Rypka, \& Hron, 2017). Hruzova, Rypka, and Hron's (2017) research noted that the fragmentation of the manufacturing process as a result of globalized trade contributes to the phenomenon where exports increase while value added nationally to production is small.

However, the literature does not seem to yield a consensus on the presence of such a relationship. Dion (2000) found that openness to trade is directly linked to the range of tradable goods in a national economy and extends beyond the manufacturing sector to primary resource sectors such as mining, crude oil, natural gas, stone, etc. Concluding that Canada's focus on exports to the United States resulted in a loss of considerable ground in the fastest growing markets; as a result Canada's aggregate trade will likely have less direct influence on terms of trade in any given market (Dion, 2000). This is supported by Rodrik (2006) and Hausmann, Hwang, and Rodrik (2007) who emphasized in their research that how country exports goods is no longer as important as what it exports. In contrast Shahbaz (2012) study using Cobb-Douglas's Production Function for long-run analysis in conjunction with the VECM Granger causality approach found that trade openness promotes national economic growth and properly shields an single economy from external shocks. This is consistent with Khan and Qayyum (2007) and Chaudhary et al. (2013). Primarily owing to the fact that the various studies have used divergent econometric methodologies to test for its presence, which have led to varied results? The conflict between methodology and results has been noted as needing further macroeconomic analysis (Hruzova, Rypka, \& Hron, 2017).

Hruzova, Rypka, and Hron (2017) engaged the Logratio statistical technique for analyzing the structure of trade flows. Their analysis distinguished capital and labour in relation to value added, breaking down trade statistics on exported goods and production components (ie: Labour) to their end-use. In comparison Dion (2000) study followed Feenstra (1998) and Hummel, Rapoport, and Yi (1998) methodology of analyzing a single source of 
data and approximated values of input-output measures. Mukhtar and Rasheed (2010), in their study on exports and imports in Pakistan, have asserted that most of the literature in the past has focused on the long-run relationship between these two variables, so as to explain the fiscal deficits witnessed in certain countries. They have further argued that if such a relation is actually present in an economy, the foreign misbalance in payments is only a short term phenomenon.

\section{Data and Methodology}

The figures in this study were based on secondary data collected from Canadian Socio-Economics Database (CANSIM). A time series data of export, import and GDP from 1981-2014 is used for inspection.

The growth rate was estimated by using the semi $\log$ or Log- Lin Model. The regression equation is as follows:

$$
Y_{t}=Y_{0}(1+r)^{t}
$$

Where $r$ is the compound (i.e. over time) rate of growth of Y. Taking the natural logarithm of equation (1) we can write:

$$
\operatorname{Ln} Y t=\operatorname{Ln} Y_{0}+t \operatorname{Ln}(1+r)
$$

Now letting,

So, the equation is as follows:

$$
\operatorname{Ln} Y_{0}=\beta_{0} \text { and } \operatorname{Ln}(1+r)=\beta_{1}
$$

$$
\operatorname{Ln} Y_{t}=\beta_{0}+\beta_{1} t
$$

Or

$$
\operatorname{Ln} Y_{t}=\beta_{0}+\beta_{1} t+\mu_{\mathrm{t}}(\text { Gujarati, 2009) }
$$

In this model, the slope coefficient measures the constant proportional or relative change in $\mathrm{Y}$ for a given absolute change in the value of the regressor $(\mathrm{t})$. That is, $\boldsymbol{\beta}_{\boldsymbol{I}}=$ relative change in regress and/absolute change in regressor.

Or

$$
\begin{aligned}
& \beta_{1}=d(\operatorname{Ln} Y) / d x \\
& \beta_{1}=(1 / y) \cdot(d y / d x)
\end{aligned}
$$

Estimates of the growth rate are calculated by taking the antilog of estimated coefficient $\beta_{1}$. The analysis further enhanced to measure the exports and imports by taking the percentage of each year's actual values from the growth values.

The Forecast value of export, import and growth rate can be spawned by various time-series analysis. However, it is essential to keep in mind the nature of the study, availability of data and efficiency of the model to be forecasted, ARIMA model was selected to forecast the imports and exports. Lags of the differentiated series presented in the forecasting equation are called, 'Auto Regressive' terms, lags of the forecast errors are called moving average. A time series which needs to be differentiated is said to be integrated version of stationary series. A non-seasonal ARIMA model is denoted by ARIMA (p, d, q), according to Box Jenkins.

To check the stationarity of the data a correlogram is used; it checks the autocorrelation and partial autocorrelation. This is the principal device to recognize ACF (autocorrelation function) and PACF (partial autocorrelation function) and resulting correlograms which are merely the plots of ACF and PACF against the lag length.

A series is stationary if the mean and auto-covariance of the series does not depend on time. A stationary series is I (0). It is important to check whether a series is stationary or not before using it in a regression.

This relates to the fact that standard interference procedures do not apply to regressions, which contain an integrated dependent variable or integrated regressors.

\section{Background Data}

\subsection{Pattern of Canadian International Trade (1981 to 2014)}

To examine the pattern of Canada's trade, the data set of total merchandise exports and imports is taken at current market prices. For this purpose, four year averages of exports and imports are used from the period 1981 to 2014 .

Table 2 show that Canadian exports and imports have both gradually increased. Except for two gaps (i.e. 1985-1988 to 1997-2000 in which total amount of imports have shown a declining trend), the total imports grow heavily. 
Table 2. Average exports and imports of Canada (\$ million at current prices)

\begin{tabular}{ccc}
\hline year & Import & Export \\
\hline $1981-1984$ & 115557750000 & 149258000000 \\
$1985-1988$ & 157898500000 & 194380500000 \\
$1989-1992$ & 198966000000 & 227756000000 \\
$1993-1996$ & 250538000000 & 315571000000 \\
$1997-2000$ & 345287500000 & 442917500000 \\
$2001-2004$ & 387566000000 & 497918500000 \\
$2005-2008$ & 485512500000 & 527120000000 \\
$2009-2012$ & 510080750000 & 483147750000 \\
$2013-2014$ & 567132000000 & 540219000000 \\
\hline
\end{tabular}

Source: Authors calculation based on CANSIM Data.

Figure 1 below shows the trend lines of Canada's merchandise exports and imports.

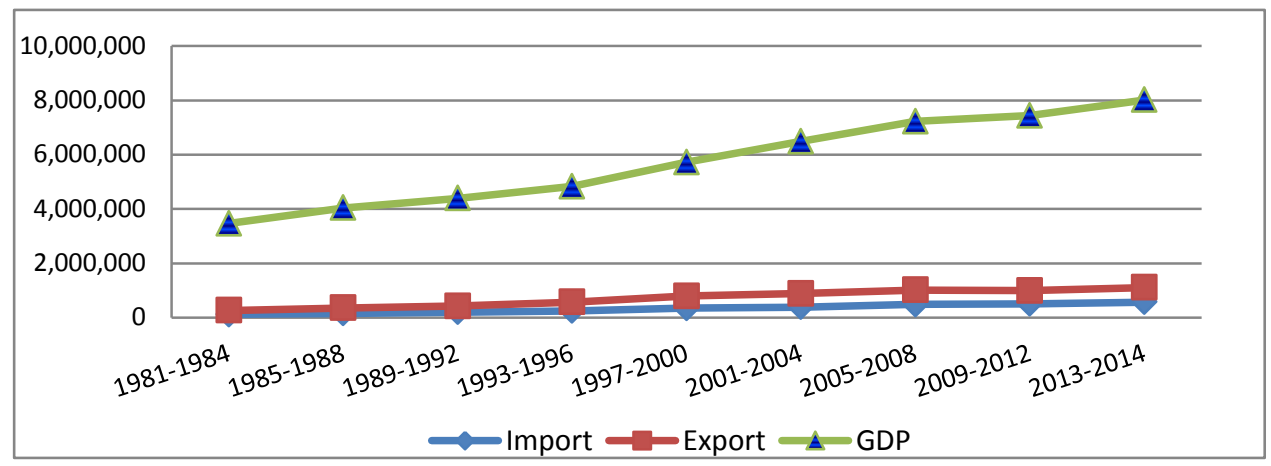

Figure 1. Imports and exports trend (Chained, 2007)

Source: Authors calculation based on CANSIM tables.

Figure 1 shows that there is an upward trend of four years average exports and imports. The gap between these two lines is narrow in the beginning but this gap is widening after the period 1993- 1996.

\subsection{Direction of Canadian Imports, Exports and GDP Since 1981- 2014 (\$ Million at Current Prices in \%)}

Figure 2 shows that for the period 1981 to 2000, the Canadian exports, imports and GDP grew at a constant rate. Another point to be noted is that the imports are less than the exports. The meltdown/recession that occurred in the Canadian economy after 2006 reversed this trend. The percentage of imports exceeded the exports, and in 2013 the imports percentage was more than the GDP as well. There is overall an increasing trend displayed by the Canadian exports, imports and GDP.

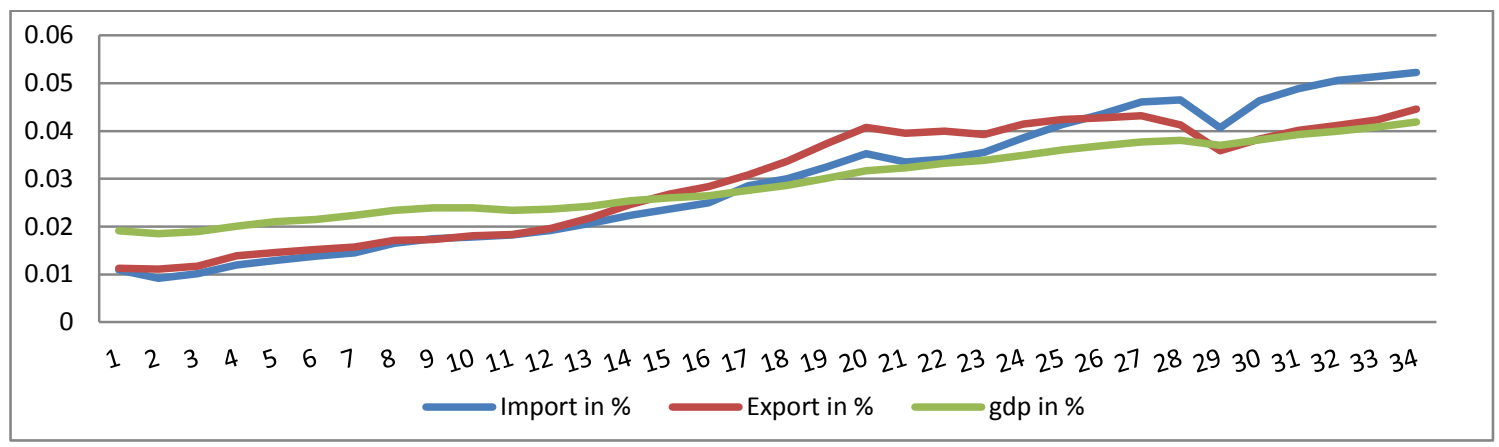

Figure 2. Direction of export, import \& GDP (\%)

Source: Authors calculation based on CANSIM tables.

\subsection{Trend of Canada's Import, Export and Trade Balance Since 1981 to 2014 (\$ Million at Current Prices in \%)}

The period 1981-2000 saw a rise in Canadian's exports, however, after 2000, imports increased rapidly, 
surpassing exports (as shown in Figure 3). This led to a negative trade balance for Canada for the period 2000-2014.

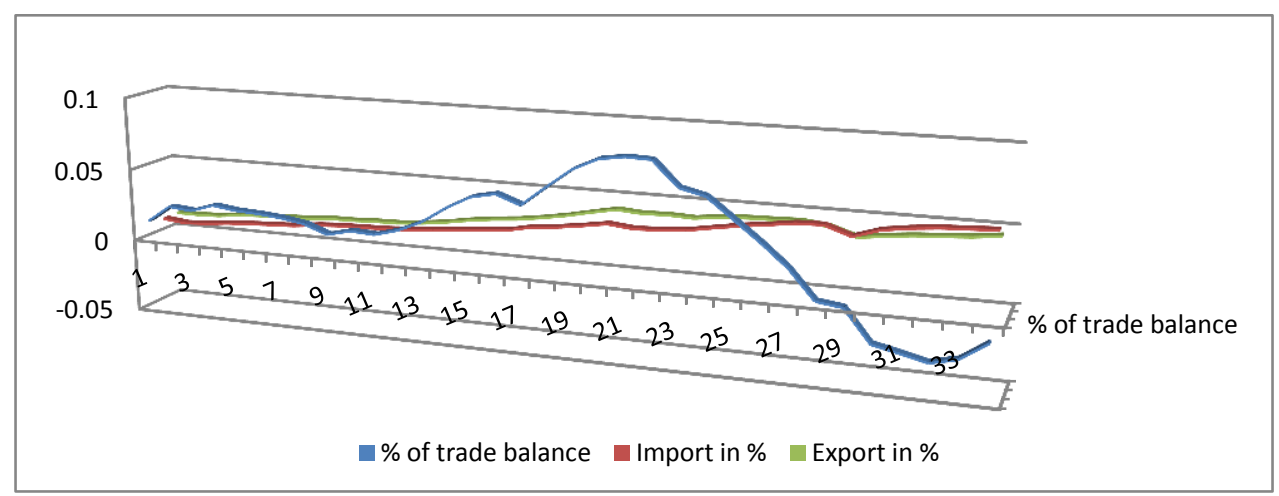

Figure 3. Canadian export, import \& trade balance (\%)

Source: Authors calculation based on CANSIM tables.

\subsection{Percentage Share of Trade Balance and Total Merchandise Trade in Canadian GDP}

From the following Figure 4, we can say that there is a wide gap between the trade balance and the total merchandise trade for Canada. Initially, the period 1980-81 witnessed a slight gap; however, it increased to a much greater extent in subsequent years. The figure also portrays that the share of trade balance in total Canadian GDP is less than the share of total merchandise trade. This gap too, is observed to be increasing after 2000. We can conclude from figure 4 that the trade balance is low, but the total trade volume is high.

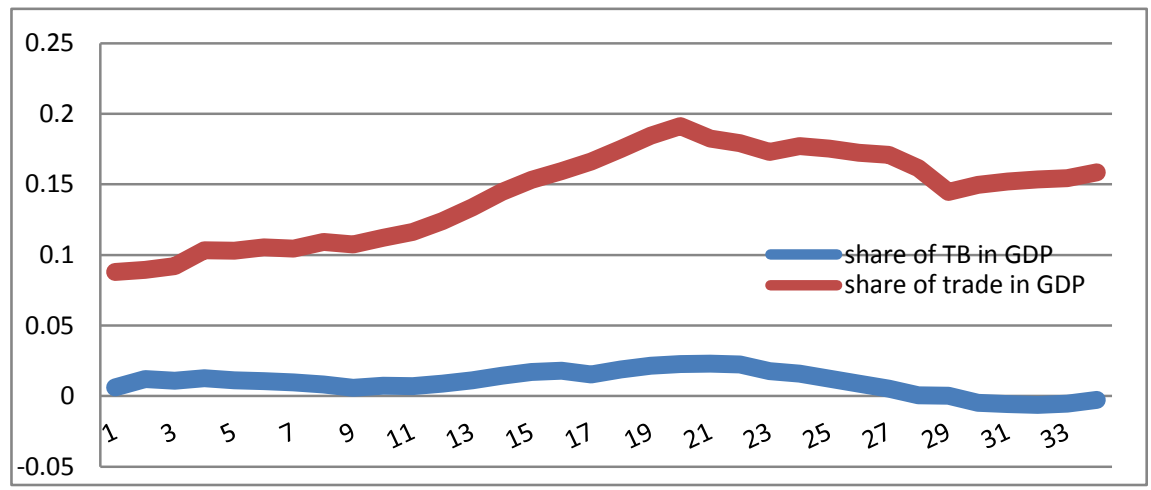

Figure 4. Canadain share of trade and trade balance in GDP (\%)

Source: Authors calculation based on CANSIM.

\section{Empirical Results of Regression Analysis}

To calculate the growth rate, log-linear model was used;

$$
\text { InM }=\beta_{0}+\beta_{1} t+\mu t \quad \text { (Where } \mathrm{Ln} \text { is natural log of import) }
$$

The dependent variable is natural $\log$ of import $(\operatorname{Ln} M)$, whereas time is taken $(t)$ as the independent variable plus some white noise error term. The results portray two kinds of growth rate: First, the instantaneous (at a point in time) rate of growth, which shows the overall growth rate for the whole period; and second, the compound growth rate which shows the growth rate of each year.

This was obtained by taking the antilog of the estimated $\beta_{1}$ and subtracting 1 from it and multiplying the difference by 100 .

$$
\text { Compound Growth Rate }=\left[\operatorname{antilog}\left(\beta_{1}\right)-1\right]^{* 100}
$$

\section{The estimated model for import is:}

$$
\text { InM }=-78.95988+0.0527311 t
$$

Imports showed a remarkable increase with $5.27 \%$ instantaneous growth rate and a slightly higher $5.41 \%$ 
compound growth rate. This was related to the fact that in 2000 the imports were greater than the exports in an absolute manner.

To calculate the growth rates of export, time is taken as an independent variable, whereas export is taken as a dependent variable.

\section{The estimated growth model of Export is:}

$$
\operatorname{InX}=-62.57846+0.0446088 t
$$

Instantaneous growth rate for exports $(\mathrm{LnX})$ calculated from these results, is $4.46 \%$ whereas compound growth rate for export is $4.56 \%$. For the entire decade of 1990, both imports and exports increased. Further, the export growth rate was less than the import growth rate. This was a result of the global meltdown in 2009. The data has further shown that the Canadian economy came under a cyclone of meltdowns or shocks during above period.

\subsection{Unit Root Test}

Before forecasting trends in exports and imports in Canada, begin by checking the stationarity of variables used in the model that must be estimated. Unit root tests have to be performed on all the variables involved to check their time series properties. For this purpose, the study uses an augmented Dickey-Fuller (ADF) unit root test. This test primarily functions to determine whether the variables to be used in the model follow a non-stationary trend (and integrated of the order 1, i.e. I(1)), or whether the data follows a stationary trend (and integrated of the order 0, i.e. I (0)).

Many macroeconomic series are observed to be non-stationary, and therefore it is important to test their order of integration.

The simple Dickey-Fuller test is limited due to the problem of autocorrelation. To tackle this problem, Dickey-Fuller has further developed a test called the augmented Dickey-Fuller (ADF) test.

$$
\begin{array}{cc}
\Delta Y t=b 1+d Y_{\mathrm{t}-1}+a i+e t & \text { Intercept Only } \\
\Delta Y t=b 1+b 2 t+d Y t-1+a i+e t & \text { Intercept and Trend } \\
\Delta Y t=d Y t-1+a i+e t & \text { No Intercept and No Trend }
\end{array}
$$

From these model equations, we can check whether the variables have a unit root or not. In order to conclude the result, all three models must provide the same decision. The ADF test is referred to as the t-statistic of $\beta_{2}$ coefficient of the following regression:

$$
\Delta X_{t-1}=\beta_{0}+\beta_{1} t+\beta_{2} X_{t-1}+\sum_{\mathrm{I}=1}^{k=1} a \Delta X_{t-1} \ldots
$$

Where $\beta_{0}$ is a constant, $t$ represents a time trend, and variable $X_{t-i}$ expresses the first difference with $\mathrm{i}^{\text {th }}$ lags. The lags are included to remove the possible serial correlations in the error terms. Akaike's Information Criterion (AIC) would be used to select the optimal lag order in the model.

The null hypothesis to be tested is that there is unit root in the series under consideration. Whereas, the alternate hypothesis is that there is no unit root in the series.

In this study, we reject the null hypothesis after the first difference. We found that the variable is non stationary at level, but after the first difference, the variable is stationary. In the ADF test, the coefficient of L1 must have a negative sign, so as to accept a given model.

\subsubsection{Unit Root Test Results}

Estimated results show that the series are non-stationary in their level form and are stationary in their first difference form. Thus, it can be concluded that EXP and IMP are integrated of order 1, i.e. I (1).

Table 2. ADF test for export and import at first difference

\begin{tabular}{ccccc}
\hline Series & \multicolumn{2}{c}{ Intercept } & \multicolumn{2}{c}{ Intercept and Trend } \\
\hline & T Statistic & C.V. (5\%) & T Statistic & C.V. (5\%) \\
$\Delta$ EXP & -4.009 & -1.697 & -4.002 & -3.572 \\
$\Delta$ IMP & -6.376 & -1.697 & -4.221 & -3.580 \\
\hline
\end{tabular}

Note. $\Delta$ represents first difference transformation \& C.V means Critical value at $5 \%$.

\subsubsection{Co-Integration}

On the basis of the theory which states that the integrated variables of order one, i.e., I (1), may have a 
co-integration relationship, it is crucial to test for the existence of such a relationship. The variables are said to be co-integrated if they are individually integrated of the same order, and also if there is at least one linear combination of these variables that is stationary. The co-integrated variables will never move far apart, and will be attracted to a long-run relationship. Testing for co-integration mainly implies testing for the existence of such a long-run relationship between economic variables. There are a number of co-integration tests, namely the Engle-Granger method (commonly known as two-step estimation procedure), the Phillips-Ouliaris methods, and the Johansen test.

\subsubsection{Johansen Test}

Johansen's procedure has an advantage over the Engle-Granger and the Phillips-Ouliaris methods, in that it can estimate more than one co-integration relationship if the data set contains two or more time series. In Johansen's cointegration test, the variable must be non-stationary at level, but when the variables are converted into first difference they must be stationary.

Johansen's procedure is nothing more than a multivariate generalization of the Dickey-Fuller test, in which he has proposed two different likelihood ratio tests, namely the trace test and the maximum eigenvalue test.

4.2 Summary of the Test Are as Follows

Table 3. Johansen Co-integration tests at level form

\begin{tabular}{|c|c|c|c|c|}
\hline \multirow{2}{*}{$\begin{array}{l}\text { Ranks } \\
0\end{array}$} & \multicolumn{2}{|c|}{ Trace statistic \& C.V. (5\%) } & \multicolumn{2}{|c|}{ Max Statistics \&C.V. (5\%) } \\
\hline & 19.4174 & 29.68 & 15.5367 & 20.97 \\
\hline 1 & 3.88077 & 15.41 & 3.6207 & 14.07 \\
\hline
\end{tabular}

Table 4. Johansen Co-integration tests at first difference

\begin{tabular}{lcccc}
\hline Ranks & \multicolumn{2}{c}{ Trace statistic \&C.V. $(5 \%)$} & \multicolumn{2}{c}{ Max Statistics \&C.V. (5\%) } \\
\hline 0 & 40.0343 & 29.68 & 22.3512 & 20.97 \\
1 & 17.68 & 15.41 & 13.2419 & 14.07 \\
\hline
\end{tabular}

Note. C.V. means critical values.

In Johansen co-integration test, if trace statistic as well as max statistic is more than the critical value at five percent, we reject the null hypothesis and accept the alternative hypothesis. But if the trace statistic and max statistic is less than the critical value, we cannot reject the null hypothesis.

The study variables, export, import and GDP are not significant at level or they are not co-integrated because the trace and max statistic is less than the 5\% critical value. But when we make a first difference of the variables (export, import and GDP) they are co-integrated.

In this study we reject null hypothesis and accept the alternative hypothesis which is desirable.

In the above table, 0 means there is no integration among variables, 1 means one co-integration, 2 means two co-integration and so on.

Table 4 shows that export, import and GDP variables are cointegrated at first difference and they have a long-run association.

\subsection{Empirical Results of ARIMA Model}

In order to identify the parameters of ARIMA or ARMA model, the first step is to view the correlogram to check for stationarity. The correlogram for both export and import variables shows that autocorrelation function dies out slowly, while the partial autocorrelation function cuts off after 2 lag. Thus, it is an ARMA process. After taking into account the differences, the data becomes stationary.

The ARIMA model thus fitted is $\operatorname{ARIMA}(1,0,0)$ for imports and $(2,0,1)$ for exports. The statistical summary for imports and exports is reported below. 
Table 5. Summary statistics for exports ARIMA $(2,0,1)$

\begin{tabular}{|c|c|c|c|c|c|}
\hline Variables & $\begin{array}{c}(1) \\
\text { Coefficient } \\
\end{array}$ & $\begin{array}{c}(2) \\
\text { t- Statistic } \\
\end{array}$ & $\begin{array}{c}\text { (3) } \\
\text { P. Value }\end{array}$ & $\begin{array}{c}(4) \\
\text { F- Statisic } \\
\end{array}$ & $\begin{array}{c}\text { (5) } \\
\mathrm{P} \text { (F-statistic) }\end{array}$ \\
\hline Constant & $\begin{array}{c}3.49 \mathrm{E}+11 \\
(1.79 \mathrm{E}+11)\end{array}$ & 1.951145 & 0.0604 & 350.7869 & $0.000000^{*}$ \\
\hline $\mathrm{AR}(2)$ & $\begin{array}{c}0.985093 \\
(0.066734)\end{array}$ & $14.76153 * *$ & $0.0000^{*}$ & & \\
\hline M.A (1) & $\begin{array}{c}0.983582 \\
(0.065701)\end{array}$ & $14.97061 * *$ & $0.0000 * *$ & & \\
\hline SIGMASQ & $\begin{array}{c}5.89 \mathrm{E}+20 \\
(1.57 \mathrm{E}+20) \\
\end{array}$ & 3.755148 & $0.0007 * *$ & & \\
\hline R-squared & 0.972283 & & & & \\
\hline Adjusted R-squared & 0.972166 & & & & \\
\hline S.E. of regression & $2.58 \mathrm{E}+10$ & & & & \\
\hline AIC & $51.02516^{*}$ & & & & \\
\hline
\end{tabular}

As we can see from the above Tables 5 and 6, the t-statistic is significant at $1 \%$ level of significance. Hence, we choose the lag1 and 2 for AR and MA at first difference, respectively.

Table 6. Summary statistics for imports ARIMA $(1,0,0$,

\begin{tabular}{|c|c|c|c|c|c|}
\hline Variables & $\begin{array}{c}\text { (1) } \\
\text { Coefficient }\end{array}$ & $\begin{array}{c}(2) \\
\text { t- Statistic }\end{array}$ & $\begin{array}{c}\text { (3) } \\
\text { P. Value }\end{array}$ & $\begin{array}{c}\text { (4) } \\
\text { F- Statisic }\end{array}$ & $\begin{array}{c}\text { (5) } \\
\text { P (F-statistic) }\end{array}$ \\
\hline Constant & $\begin{array}{c}3.44 \\
(1.970)\end{array}$ & 1.742696 & 0.0913 & 577.2908 & $0.000000^{*}$ \\
\hline $\mathrm{AR}(1)$ & $\begin{array}{c}0.993601 \\
(0.032481)\end{array}$ & $30.58982 * *$ & $0.000000^{*}$ & & \\
\hline Sigmasq & $\begin{array}{c}5.8720 \\
(1.3320\end{array}$ & $4.426813^{* *}$ & $0.0001 * *$ & & \\
\hline R-squared & 0.973852 & & & & \\
\hline Adjusted R-squared & 0.972166 & & & & \\
\hline S.E. of regression & 2.5410 & & & & \\
\hline AIC & $50.96465^{*}$ & & & & \\
\hline
\end{tabular}

Note. The values in parentheses are Standard Error of the parameter. The asterisks $* *$ indicate $5 \%$ level of significance and $*$ indicate Adjusted R Square, P Value of F-statistic and AIC value to show to goodness of fit of the model respectively.

\subsection{Forecasting Using ARIMA}

From the model we calculated the export and import values which are shown below. Over a period of time Canadian exports and imports increase and have an increasing trend. Export increases more than Import as shown in Table 6.

The ARIMA forecast results show that Canadian exports are expected to reach $\$ 560,455,746$ dollars at current market prices by 2020. The graph forecasting exports also shows an upward trend (see Figure 5). On the other hand, the forecast for imports shows expected decreases during the forecasted period. The forecast values of imports are anticipated at $\$ 545,130,244$ millions dollars at current market prices by the year 2020 . The imports graph also shows a downward trend during the forecasted period (see Figure 5). But the expected growth in exports is higher than the expected increase in imports which is desirable for the country's economic growth.

Average Canadian imports and exports are increasing in real terms. However, the Canadian economy has recently suffered a series of meltdowns/shocks which has drastically overturned the foreign trade scenario in the country. The study reveals that Canadian trade balance has grown negatively due to many shocks which are undesirable for an economy.

The repeated meltdowns have led to a complete reversal in the trends displayed by imports, exports, and GDP. The constant growth rate of the 3 economic variables before the recession in 2000 was found later to indicate an increasing trend for all of the 3 variables. Particularly, the recession that occurred resulted in the sharp increase in imports which exceeded the exports, and in 2013 the imports even closed the GDP level. Thus, the prevalent offset in the trade balance owed to global economic turmoil. 
From the results of the forecasts featured in the present study, we can expect the trade balance situation of the Canadian economy to improve. The GDP too, is expected to at least approach par (if not increase) with the study variables.

Table 6. Forecasting values of ARIMA model for import and export

\begin{tabular}{cccc}
\hline Year & Periods & Forecast values of Import & Forecast Values of Exports \\
\hline 2015 & 1 & 551009978200.75 & 558414464788.26 \\
2016 & 2 & 551106747270.25 & 568137059370.66 \\
2017 & 3 & 548000728753.45 & 554704052874.20 \\
2018 & 4 & 548096055250.02 & 564264008923.33 \\
2019 & 5 & 545036339320.06 & 551055708337.98 \\
2020 & 6 & 545130244748.67 & 560455746454.01 \\
\hline
\end{tabular}

Source: Forecasting values calculated by author.

4.5 Graphical Representation of the Forecast of Export and Import Values Using ARIMA Model Form 2015 to 2020

From Table 6, the Canadian export increase over a period of time slightly higher from import and import also increases less than the import. From the figure we can say that exports increase in a cyclical fashion or in irregular manner; on the other hand imports decrease somewhat smoothly.

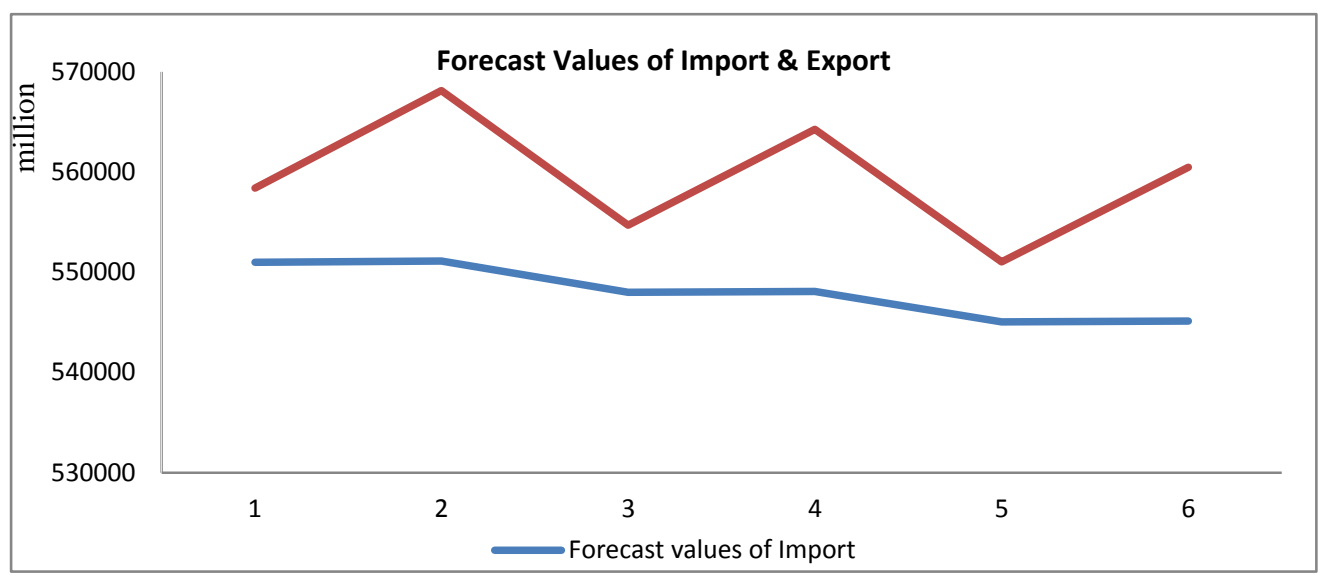

Figure 5. Canadian expected trend of export

Source: Authors calculation based on CANSIM.

\section{Conclusion}

The Canadian economy has an enough exposure to the global market; the Canadian merchandise trade has an upward trend that affects the exports and imports arising from Canada as well as the output of other related economies. From the present study, we can say that fluctuations in the global price level of commodities will have no direct influence on Canada's terms of trade.

The study shows an increasing trend both for imports and exports during the study period. The study results also reveal that Canadian merchandise exports and imports are expected to increase in the future and become a determining source of income for the global economic integration. Further, the economy seems to be an emerging source of attraction for foreign trade.

The regression analysis conducted on the growth rate of imports (instantaneous \& compound) is higher than the growth rate of exports. This too, has its roots in the various shocks experienced by the economy.

The results have indicated that there exists a cointegrated long-run relationship between the study variables. This knowledge about the cointegration between exports and imports is vital for macroeconomic policy makers, so as to assist them in successfully achieving an external balance.

Canada, being among the top producers and suppliers of many commodities such as crude oil, cars, chemical 
fertilizers, lumber, seafood, etc., is a significant contributor to the world economy, and its economic importance is believed to increase in the expected future, given the continuous increase in demand for such durables and non-durables goods. This interdependence between countries also points out that considering both the home country environment as well as that prevailing in the international boundaries, is vital for determining the countries trade patterns and its related dynamics.

\section{References}

Abdulai, A., \& Jacquet, P. (2002). Exports and economic growth: Cointegration and Causality evidence for Cote d'Ivoire. African Development Review, 14(1), 1-17. http://dx.doi.org/10.1111/1467-8268.00043

Anwar, A. M. R., Nasreen, S., \& Chaudhary, M. K. (2013). Patterns of trade and its future prospects in Pakistan. A time-series analysis. British Journal of Arts and Social Sciences, 13(2).

Bloskie, C., Clarke, S., \& Gellatly, G. (2015). Recent developments in the Canadian economy: Spring 2015. Retrieved from http://www.statcan.gc.ca/pub/11-626-x/11-626-x2015043-eng.pdf

Box, G. E. P., \& Jenkins, G. M. (2015). Time Series Analysis: Forecasting and Control. Holder Day, San Francisco.

Chen, H. (2009). A literature review on the relationship between foreign trade and economic growth. International Journal of Economics and Finance, 1(1). http://dx.doi.org/10.5539/ijef.v1n1p127

Dion, R. (1999-2000). Trends in Canada's merchandise trade. Research Department, Bank of Canada review. Retrieved from http://www.bankofcanada.ca/wp-content/uploads/2010/06/r001c-e.pdf

Feenstra, R. (1998). Integration of Trade and Disintegration of Production in the Global Economy. Journal of Economic Perspectives, 12(4), 31-50. http://dx.doi.org/10.1257/jep.12.4.31

Ghafoor, A., \& Hanif, S. (2008). Analysis of the trade pattern of Pakistan: Past trends and future prospects. JOURNAL OF AGRICULTURE \& SOCIAL SCIENCES. Retrieved from http://aocrj.org/wp-content/uploads/2012/08/Forecasting.pdf

Gujarati, D. N. (2003). Basic Econometrics. McGraw-Hill Higher Education, New York.

Hausmann, R., Hwang, J., \& Rodrik, D. (2006). What you export matters. Journal of Economic Growth, 12(1), 1-25. http://dx.doi.org/10.1007/s10887-006-9009-4

Hruzova, K., Rypka, M., \& Hron, K. (2017). Compositional Analysis of Trade Flows Structure. Austrian Journal of Statistics, 26, 49-63. http://dx.doi.org/10.17713/ajs.v46i2.569

Hummels, D., Rapoport, D., \& Yi, K. M. (1998). Vertical specialization and the changing nature of world trade. Retrieved from https://www.newyorkfed.org/medialibrary/media/research/epr/98v04n2/9806humm.html

Khan, M. A., \& Qayyum, A. (2007). Dynamic Modelling of energy and growth in south Asia. The Pakistan Development Review, 46(4), 481-498. $\quad$ Retrieved from http://www.pide.org.pk/pdf/PDR/2007/Volume4/481-498.pdf

Krugman, P. (1992). Geography and trade. Retrieved from https://mitpress.mit.edu/books/geography-and-trade

Muhammad, R., Anwar, A., \& Chaudhary, M. A. (2013). Patterns of trade and its future prospects in Pakistan: A time-series analysis. British Journal of Arts and Social Sciences, 13, 2046-9578. Retrieved from http://www.bjournal.co.uk/paper/BJASS_13_2/BJASS_13_02_05.pdf

Mukhtar, T., \& Rasheed, S. (2010). Testing Long Run relationship between exports and imports: Evidence from Pakistan. Journal of Economic Cooperation and Development, 31(1), 41-58. Retrieved from http://library.sesrtcic.org/jecd/jecd_articles/ART08121502-2.pdf

Rodrik, D. (2006). What's so special about china's exports? China World Economy, 14(5), 1-19. http://dx.doi.org/10.1111/j.1749-124x.2006.00038.x

Sawyer, J., \& Linnemann, H. (1967). An Econometric Study of International Trade Flows. The Canadian Journal Of Economics And Political Science, 33(4), 633. http://dx.doi.org/10.2307/140051

Shahbaz, M. (2012). Does trade openness affect long run growth? Cointegration, causality and forecast error variance decomposition tests for Pakistan. Economic Modelling, 29, 2325-2339. http://dx.doi.org/10.1016/j.econmod.2012.07.015

Statistics Canada, International, \& Analysis, E. P. (2016, August 2). Canada's state of trade: Trade and investment update - $2016 . \quad$ Retrieved January 20, 2017, from 
http://www.international.gc.ca/economist-economiste/performance/state-point/state_2016_point/index.aspx ?lang=eng

Statistics Canada. (1989a). Statistics Canada. Merchandise trade-Exports, 1988. Catalogue 65-202. Ottawa: Statistics Canada.

Statistics Canada. (1989b). Statistics Canada, Merchandise trade -Imports, 1988. Catalogue 65-203. Ottawa: Statistics Canada, 1989b

\section{Copyrights}

Copyright for this article is retained by the author(s), with first publication rights granted to the journal.

This is an open-access article distributed under the terms and conditions of the Creative Commons Attribution license (http://creativecommons.org/licenses/by/4.0/). 